\title{
Ewa WOJTOWICZ
}

\section{STEREOTYPES IN MANAGEMENT - DOES LEADERSHIP HAVE A GENDER?}

\begin{abstract}
The aim of this article is to indicate the role of gender stereotypes in management and their significant impact on the perception of leaders and on the management styles of organizations, depending on the gender of the leader. Although the topic has been explored by researchers and practitioners for years, it still seems important from the perspective of leaders' career paths. In this context, the present article attempts to review and analyze the past literature on gender stereotypes and their differences, similarities, and perceptions in relation to leadership styles. Research shows that gender patterns influence the perception of leaders by employees, as well as by leaders themselves. Women and men in managerial positions tend to perform their roles differently, the reasons for this being attributable to the internalization of gender roles defined by gender stereotypes. Therefore, it is critical for organizations to incorporate gender diversity management in the workplace.
\end{abstract}

Keywords: Leadership, gender, gender stereotype, management.

\section{INTRODUCTION}

Socio-cultural transformations, civilizational and cultural development and globalization are processes that strongly determine the internal and external environment of an organization, forcing it to constantly monitor and quickly respond to the changes taking place. Transformations in the organisational environment are an impulse to verify the current solutions, to explore innovative methods, methodologies and tools suitable for managing complex company structures and to seek new opportunities for organisational development. Nevertheless, in the era of access to similar technologies, tools and opportunities to gain knowledge, what makes the organization competitive is the employees' professional potential. Particular importance is attached to the quality of managerial staffs and the search for the profiles of the best managers.

For many years, the analysis of the leadership phenomenon has also been becoming an intensively explored field of research in the area of social sciences. In order to meet the management needs, researchers verify various models, identify barriers to the implementation of good management practices and define effective leadership taking into account the characteristics of the organisation and its employees. Gender, as research shows, is one of the characteristics that influence recruitment processes and the final organisational

\footnotetext{
${ }^{1}$ Ewa Wojtowicz, PhD, Warsaw Management University in Warsaw, Institute of Pedagogy and Psychology, ul. Kawęczyńska 36, Warszawa 03-772; e-mail: eva.wojtowicz@ gmail.com. ORCID: 0000-0001-8520-8238.
} 
structure. Like age, it is one of the most universal indicators of social stratification. The causes of this state of affairs are seen in the fact that the biological sex is understood to also include the socio-cultural features that influence the formation of an individual's identity and its perception by its environment (Mandrysz, 2003).

A review of the statistics reveals an imbalance between the number of women and men in managerial positions, both in the world and in Poland - women are an under-represented group among managers (e.g. raport Grant Thornton, 2019; Duncan, Cassells, 2019). And although there are differences between individual countries in Europe, the overall proportion of women is lower than men (EIGE, 2019) According to the data from the European Commission, only one in three managers in the European Union is a woman (Eurostat, 2019). In Poland, the data discussed by Dzwigoł-Barosz (2015) show that 30\% of Polish companies have women on the boards but only $4 \%$ hold the rank of president. This is so despite the fact that companies with more women on the boards are characterised by better corporate governance, business ethics and financial management (e.g. Kowalski, 2011; Hunt, Layton, Prince, 2015, Delloite, 2012; Franke, 1997).

\section{LEADERSHIP IN A MODERN ORGANISATION}

Any attempts to define the concept of leadership present many difficulties. This construct, which occupies an important place in business practice, has been given a number of definitions highlighting its various aspects. In the most general sense, a leader is any person considered to be managing a specific project, an internal organisational unit or an entire company. The leaders are therefore all members of the organisation acting as supervisors, including entrepreneurs - owners of their own businesses. R. Griffin includes all those whose primary responsibility is to carry out the management process, regardless of their position in the organisation (Griffin, 2004). The category of leaders also includes all those whose role is to make sure that goals are achieved by teams or to determine and coordinate work activities of others (Listwan, 1995; Kisielnicki, 2005). In a narrower sense, the term leader is understood as referring to a specific group of employees. Stoner (1999) identifies a leader as a member of the senior management team responsible for the overall management of the organisation.

In recent years and along with the shift towards the humanistic concepts of authentic leadership, a distinction has emerged in the literature focused on demonstrating the differences between a leader and a manager (T. Oleksyn, A. E. Oleksyn, 2008). It is assumed that leadership is associated with concepts such as vision, inspiration, getting people's commitment to achieving goals and indicating directions of change while the leader themselves become a role model for others. Management, on the other hand, manifests itself in the implementation of the tactical functions of controlling, motivating, budgeting, planning and organising as well as making decisions. Therefore, various types of leaders are needed in order to carry out the more and more complex organisational tasks. It is important to take care to make sure that people are properly suited to the particular challenges. By referring these differences to the organisational practice, it can be seen that it is not the name of the position that defines a leader but the scope of the tasks they perform. The manner they are performed depends on many factors that lie within the organisation itself as well as within the particular employee attributes (e.g. experience, education or personality). One of such factors is gender and adjustment of leaders' behaviours to the 
requirements of gender-related roles as well as the way leaders are perceived by employees where such perception is determined by stereotypes.

\section{THE ROLE OF GENDER AND GENDER STEREOTYPES IN MANAGEMENT}

The impact of stereotypes on various spheres of the functioning of women and men has been the subject of interest among researchers in the humanities and social sciences for years. It would seem that the rich literature on the subject has already dealt with all the contexts for talking about the relations between gender and the labour market and management. However, the constant evolution of the stereotypes forces constant monitoring and verification of the changes in the very content of the stereotypes and their perception by the stereotyped people as well as a change concerning the requirements ensuing from the social views on an employee's gender (e.g Eagly, Nater, Miller, Kaufmann, Sczesny, 2019; Sule, Seda, Kubilay, Loranth, 2019; Majcher, 2012; Lipińska-Grobelny, Gorczycka, 2011).

As Moczydłowska (2017a, 2017b) writes, gender as a variable associated with a divergent attitude towards management has been present in academic works since the 1970s, mainly in the context of seeking gender-related differences between management styles. In the 1980s, researchers focused on analysing the natural differences between genders treating them as valuable diversity for organisations. Currently, there is a dispute among researchers about the nature of these differences. Are they real or apparent, and do they predispose one gender more than the other to engage in management?

Stereotypes are views, opinions, judgments and superstitions that go beyond mere categorisation. These fundamentally false generalisations refer to a group where identical characteristics are attributed to all its members, regardless of the real differences between them (Aronson, Wilson, Akert, 1997). The sources of stereotypes can be specified as individual or social. The social ones are related to the patterns of behaviour accepted in a particular community while the individual ones result from personal experience and certain features related to perceiving reality. Some of the most frequently appearing stereotypes are those related to gender; hence, their impact on the social reality cannot be underestimated. Gender categorisation already exists in two-year-old children. It is acknowledged that at this age they already have a notion of masculinity and femininity (Vasta, Haith, Miller, 2001). This means that many gender differences are not based on biology but are related to each individual' socialisation experiences (Giddens, 2004).

In general, all the characteristics contained in gender stereotypes have a bipolar distribution. They can be broken down into typically male (instrumental) and typically female (expressive) features. The former are valued higher in most cultures. Stereotypes related to genders and the gender roles pertaining to them regulate social behaviour of women and men in every society - they contain in them culturally defined behavioural characteristics of women and men (Mandal, 2004). The influence of stereotypes is primarily revealed in the attributes ascribed to the particular individuals and the assumption that they are more predisposed to certain activities. Thus, in most cultures, the content of the male stereotype includes traits related to physical strength, domination, action orientation, selfsufficiency and independence, but also aggressiveness or egoism. On the other hand, the stereotypical image of a woman describes her as kind, delicate, passive, characterised by interpersonal sensitivity and empathy, but also emotionally unstable and rather not resistant to stress (e.g. Mandal, 2003; Deaux, Lewis, 1984). Thus, the distinguishing features of men 
are activity and action, and the characteristics of women are interpersonal sensitivity and relationships with people (Królikowska, 2011). However, as Mandal (2005) writes, 'it also turns out to be wrong to assume that women and men only have their own gender specificity because features treated as typically male or typically female are found in representatives of the opposite sex'.

In order to properly understand the role of stereotypes in management, the focus should be on how they can affect managerial staff. Children are expected to behave in a specific way from birth and their consistency with the gender is subject to constant social control. E. Mandal (2004) conducted a review of studies which shows that even children as young as 3 years show greater interest in gender-specific activities which increases with age. Behaviours inconsistent with the cultural stereotypes will be criticised, and those that are gender-specific are socially acceptable. Thus, women and men build their identity based on the internalisation of social expectations. As a result, there are many gender differences affecting different spheres of life, including work. Men, for instance, have a higher self-esteem than women and this is associated with a more positive assessment of their own competence than in women. Women, in turn, are more reluctant to make risky decisions and to decide for others. Women are also characterised by a stronger openness towards people expressed in altruistic attitudes and they also better read signals indicating socially approved behaviours. Research also shows that with age the level of anxiety decreases in men while it increases in women (Croson, Gneezy, 2009). Compared with men, women are also characterised by a lower self-assessment of their own management skills and lower levels of leadership aspirations (Fritz, van Knippenberg, 2019; Pufal-Struzik, 2017; Hisrich, Brush, 1984).

\section{THE IDEAL LEADER AND THE GENDER}

There are three strands in the literature that define effective leaders, i.e. emphasising personality traits, focusing on behavioural patterns as well as situational theories that emphasise the adjustment of leadership strategies to different conditions. Nowadays, concepts indicating natural leadership potential based mainly on authenticity and emotional intelligence can also be found. It seems that just like the number of definitions of leadership itself, the number of attributes of the ideal leader is infinite. Just to show their multitude, some examples can be mentioned: self-discipline, diligence, honesty and ethics, emotional self-control and balance, communication skills, speed and high quality of decisions, motivating and inspiring others, self-confidence, empathy, charisma, ability to set shortand long-term goals, ability to reward, attitude to employee development and perception of resources, ability to build conflict-free relationships based on respect and trust, initiative, resistance to stress, objectivity, ability to admit mistakes, accepting mistakes in others, setting challenges, being fair.

At the same time, the characteristics that are not accepted in a leader include lack of assertiveness, passivity, difficulty in making decisions and excessive emotionality. As can be easily seen, these traits are often mentioned as those that characterise women - for it is commonly believed that leaders have traits more strongly associated with aggressive attitudes than social ones, and the leader stereotype is closer to that of a man than that of a woman (Butterfield, Parent, 2002). Therefore, in social perception, effective leadership is identified with masculinity, and men are indisputably predisposed to perform managerial roles. As a consequence, women are considered incapable of performing managerial roles, 
and their leadership style is associated with lower effectiveness (Górska, 2016). In addition, women in managerial positions have to face the conflicting expectations placed on them (Newport, 2001). On the one hand, they are expected to exhibit manifestations of the feminine stereotype (e.g. ability to form relationships or gentleness); on the other hand, to be consistent with a more masculine leadership stereotype (e.g. being aggressive or independent). This contrast is also one of the barriers to women's advancement - in many masculinised organisations stereotypically female traits are treated as a manifestation of weakness and lack of leadership competence.

Economic transformations will, however, force changes in the perception of women in the roles of leaders and entrepreneurs. In complex structures that pursue their goals in an unpredictable economic reality, increasingly more importance is being given to the relational and emotional contexts of work. Therefore, as Goleman writes, "the old leaders will have to learn new tricks' (Goleman, Boyatzis, McKee, 2002). He stresses the responsibility of leaders in the face of the changes taking place in contemporary organisations to create emotionally intelligent organisations in order to provide employees with a positive, healthy, relational capital-based work environment. Given the results of research in such organisations, effective leaders will be required to use the attributes currently considered to belong to the female sphere.

The issues of stereotypes in management are usually considered from two angles, i.e. their impact on the functioning of leaders and the perception of leaders through the prism of gender characteristics. Some of the most frequently analysed variables in the context of gender in management are management styles. Typologies of styles can be found in the literature. However, most of them can be described by means of a dichotomous division. Those most frequently described include (e.g. McCleskey, 2014; Piskorz, 2012; Czerw, Babiak, 2010; Mrówka, 2010; Żukowski, Galla, 2009; Penc, 2007: Mroziewski, 2005; Koźmiński, Piotrowski, 2000; Bass, 1997):

a) task-oriented vs relationship-oriented leadership:

A task-oriented leader is interested in doing the job, and their influence is related to task control. Relationship-oriented leadership, on the other hand, presupposes a focus on positive emotions and the right relationship in the course of performing the tasks.

b) transactional style vs transformational style:

Transformation is about emotions, values, ethics, long-term goals and includes an assessment of motives and the ability to meet employees' needs. Transformation leaders inspire and motivate and encourage professional development. Transactional leaders, on the other hand, focus on task control, reward and punish while focusing on performance.

c) authoritarian style vs democratic style:

The authoritarian style is characterised by distribution of tasks among employees without the involvement of the leader. Interaction takes place mainly through orders, instructions and penalties. A feature of the democratic style is the focus on teamwork and group decision-making concerning ways of achieving objectives.

It can be noticed that these styles reflect gender stereotypes. The majority of research in the Polish and foreign literature characterises the female management styles as being transformative, more democratic (participatory) and more employee-oriented. Conversely, the transactional, authoritarian (directive) and task-focused style characterises the male management strategies (Leithwood, Jantzi, 2005; Eagly, Carli, 2003). 


\section{PREFERENCES FOR LEADERSHIP STYLES AND PERCEPTION OF THE LEADER THROUGH THE PRISM OF GENDER}

Reviews of concepts and studies also point to differences in preferred management styles depending on the gender of the leader. Women, in contrast to the male prescriptive and controlling management styles, are more likely to choose styles based on relationships and community. In general, comparative research results highlight women's propensity for democratic leadership styles and their preferences for teamwork. Unlike women, men are more likely to adopt an autocratic and task-oriented style (van Engen, Willemsen, 2004). Women, on the other hand, value the transformational style higher and men the transactional style (Cuadrado, Navas, Molero, Ferrer, Morales, 2012). According to Dzwigosz-Barosz (2018), 'women use "management by love" and men "management by fear". In the author's opinion, men are characterised by being more ruthless in pursuing their goals, adopting faster decision-making processes and having a greater willingness to take risks than women, who are more conscientious, cooperative and more likely to see emotions in others.

Women and men in managerial positions tend to perform their roles differently, the reasons for this being attributable to internalisation of gender roles defined by the gender stereotype (e.g. Sebastian, Moon, 2017; Lyness i Heilman, 2006). These findings are supported by Polish studies which used the five-factor personality model (FFM, the Big Five) to examined personality differences between women and men in managerial positions and the levels of emotional intelligence. It turns out that women, as compared with men, are characterised by significantly higher neuroticism, openness to experience and amicability. Men are also characterised by a lower level of emotional intelligence than women, largely responsible for the ability to build relationships with others and for openness to people. These traits may support the above discussed tendencies to choose particular styles of managing others (Babiak, Bajcar, Borkowska, 2017).

Polish research conducted by Moczydłowska (2017a, 2017b) also shows that employees perceive their leaders differently depending on their gender. As it turns out, perception of leaders has also repeatedly been consistent with gender stereotypes. Respondents associated male leaders with features of the gender stereotype, i.e. 'determined, demanding, responsible, authoritarian, and ambitious.' According to the respondents, a make manager is self-confident, rivalrous visionary with a tendency to manipulate others, high emotional resilience, lack of empathy and orientation towards subordinates. On the other hand, female leaders were characterised by conscientiousness, care for the emotional atmosphere at work, poor resistance to stress and frustration, and excessive emotionality. They were also attributed with high ambitions and excessive requirements imposed on employees, and a lack of tolerance for errors. These traits were also attributed to men. The author of the study concludes that managerial effectiveness is influenced by a variety of variables where gender and the related stereotypes strongly affect evaluations of leaders even though personality can play a significantly greater role.

\section{SUMMARY}

The crucial condition necessary for an organisation to succeed is the quality of management understood as its effectiveness in achieving the company's goals. Therefore, both theoretical considerations and empirical research in this area include searching for such traits of leaders that increase the chances for effective implementation of this scenario. However, in the business world there are many stereotypes related directly to the gender of 
leaders and thereby to the way of fulfilling managerial roles. In order to increase the effectiveness of modern organisations, the inclusion of gender management in the wider area of diversity management will soon become a necessity due to the increasing number of women in the labour market and the changing career paradigms. This is likely to weaken gender stereotypes and their impact on the perceptions of leaders while it is their effectiveness in implementing the diverse tasks facing the organisation that will become crucial.

\section{REFERENCES}

Aronson, E., Wilson, T. D., Akert, R. M. (1997). Psychologia spoteczna - serce i umyst. Poznań: Wydawnictwo Zysk i s-ka.

Babiak, J., Bajcar, B., Borkowska, A. (2017). Kobiety i mężczyźni na stanowiskach menedżerskich - wyolbrzymione czy niedoszacowane różnice? "Zarządzanie Zasobami Ludzkimi" nr 1(114).

Bass, B.M. (1997). Does the Transactional-Transformational Leadership Paradigm Transcend Organizational and National Boundaries? "American Psychologist” No. 52.

Butterfield, D. A., Parent, J. D. (2002). Gender and managerial stereotypes: Have the times changed?"Journal of Management" No. 28.

Croson, R., Gneezy, U. (2009). Gender differences in preferences. "Journal of Economic literature" No. 47(2).

Cuadrado, I., Navas, M., Molero, F., Ferrer, E., Morales, J.F. (2012). Gender Differences in Leadership Styles as a Function of Leader and Subordinates' Sex and Type of Organization. "Journal of Applied Social Psychology" No 42 (12).

Czerw, A., Babiak, J. (2010). Transformacyjny styl kierowania $w$ tworzeniu pozytywnej organizacji. "Zarzadzanie Zasobami Ludzkimi” nr 6(77).

Deaux K., Lewis L. (1984). The structure of gender stereotypes. Interrelationship among components and gender label. "Journal of Personality and Social Psychology" No. 46.

Delloite (2012). Kobiety $i$ władza w biznesie Czy płeć ma znaczenie dla budowania pozycji $i$ wptywu $w$ organizacji? [Access: 18.12.2019]. Access on the internet: https://www2. deloitte.com/content/dam/Deloitte/p1/Documents/Reports/pl_Raport_Deloitte_Kobiety_ Wladza_2012.pdf

Duncan, A., Cassells, E. (2019). Gender Equity Insights 2019: Breaking through the Glass Ceiling, BCEC [Access: 04.01.2020]. Access on the internet: https://bcec.edu.au/ publications/gender-equity-insights-2019-breaking-through-the-glass-ceiling/

Dźwigoł-Barosz, M. (2015). Lider a płeć. “Zeszyty Naukowe Politechniki Śląskiej. Organizacja i Zarzadzanie” nr 78 (1928).

- (2018) Zarządzanie innowacyjnym przedsiębiorstwem przez wspótczesnego menedżera, VI Sympozjum Naukowe "Ukraina - Polska - współpraca synergetyczna", Ukraina.

Eagly, A. H., \& Carli, L. L. (2003). Finding gender advantage and disadvantage: Systematic research integration is the solution. "Leadership Quarterly" No. 14. DOI: 10.1016/ j.leaqua.2003.09.003.

Eagly, A.H., Nater, Ch., Miller, D. I., Kaufman M., Szczesny, S. (2019). Gender Stereotypes Have Changed: A Cross-Temporal Meta-Analysis of U.S. Public Opinion Polls From 1946 to 2018. American Psychologist Advance online publication (No Pagination Specified). DOI: $10.1037 / \mathrm{amp} 0000494$. 
European Institute for Gender Equality (EIGE, 2019). Gender Equality Index 2019. Work-life balance (domain: power and work). Access on the internet: https://eige.europa.eu/

Eurostat (2019). "8 March 2019: International Women's Day. Only 1 manager out of 3 in the EU is a woman... ... even less in senior management positions" Vol 43, 7 march [Access: 20.12.2019]. Access on the internet: https://ec.europa.eu/eurostat/documents/2995521/ 9643473/3-07032019-BP-EN.pdf/e7f12d4b-facb-4d3b-984f-bfea6b39bb72

Franke, G. (1997). Gender Differences in Ethical Perceptions of Business Practices: A Social Role Theory Perspective. "Journal of Applied Psychology” nr 82(6). DOI: 10.1037/00219010.82.6.920.

Fritz, C., van Knippenberg, D. (2019). Gender and Leadership Aspiration: Supervisor Gender, Support, and Job Control. "Applied psychology: an international review" $\mathrm{nr} 0$ (0). DOI: 10.1111/apps.12197.

Goleman, D., Boyatzis, R., McKee, A. (2002). Primal leadership: Realizing the power of emotional intelligence. Boston: Harvard Business School.

Giddens, A. (2004). Socjologia. Warszawa: Wydawnictwo Naukowe PWN.

Górska A. M. (2016). Gender Differences in Leadership. "Studia i Materiaty” No. 1(20)

Grant T. (2019). Women in Business: Building a Blueprint for Action [Access: 04.01.2020]. Access on the internet: https://www.grantthornton.global/globalassets/global-insights---donot-edit/2019/women-in-business/gtil-wib-report_grant-thornton-spreads-low-res.pdf

Griffin, R. (2004). Podstawy zarzadzania organizacjami. Warszawa: PWN.

Hisrich, R., Brush, C. (1984). The Woman Entrepreneur: Management Skills and Business Problems. "Journal of Small Business Management” No. 22 (1).

Hunt, V., Layton, D., Prince, S. (2015). Raport “Why Diversity Matters” [Access: 10.12.2019]. Access on the internet: https://www.mckinsey.com/ /media/McKinsey/Business $\% 20$ Functions/Organization/Our\%20Insights/Why\%20diversity\%20matters/Why\%20diversity $\% 20$ matters.ashx

Kisielnicki, J. (2005). Encyklopedia biznesu. Warszawa: Fundacja Edukacja.

Kowalski, J. K. (2011). Kobiety brylują w biznesie. Przybywa téz pań, które przynosza do domu więcej pieniędzy niż mężowie [Access: 17.12.2019]. Access on the internet: http://biznes.gazetaprawna.pl/artykuly/505499,kobiety_bryluja_w_biznesie_przybywa_tez _pan_ktore_przynosza_do_domu_wiecej_pieniedzy_niz_ich_mezowie.html

Koźmiński A., Piotrowski W. (2000). Zarządzanie - teoria i praktyka. Warszawa: PWN

Królikowska, S., (2011). Rola stereotypów ptci w kształtowaniu postaw kobiet i mężczyzn wobec zdrowia, „Nowiny Lekarskie” nr 80(5).

Leithwood, K., Jantzi, D. (2005). A Review of Transformational School Leadership Research 1996-2005. "Journal Leadership and Policy in Schools" No. 4(3). DOI: 10.1080/ 15700760500244769.

Listwan, T. (1995). Ksztattowanie kadry liderskiej firmy. Wrocław: Wydawnictwo Kadry

Lyness, K. S., Heilman, M. E. (2006). When Fit is Fundamental: Performance Evaluation and Promotions of Upper Level Female and Male Managers. "Journal of Applied Psychology" No. 91. DOI: 10.1037/0021-9010.91.4.777.

Lipińska-Grobelny, A., Katarzyna Gorczycka, K. (2011). Rekonstrukcja narzędzia do pomiaru ptci psychologicznej. "Przegląd Psychologiczny” nr 54(2). 
Majcher, M. (2012). Próba uchwycenia wizerunków płci i ich przemian: Cechy przypisywane kobietom i mężczyznom oraz ich miejsce wśród pożądanych cech Ja. Praca doktorska. Repozytorium UW [Access: 10.01.2020]. Access on the internet: http://depotuw.ceon.pl/ handle/item/163

Mandal, E. (2003). Kobiecość i męskość. Popularne opinie, a badania naukowe. Warszawa: Wydawnictwo Naukowe Żak.

(2004). Podmiotowe i interpersonalne konsekwencje stereotypów zwiąanych z ptcia (wyd. II). Katowice: Wydawnictwo Uniwersytetu Śląskiego.

— (2005). Osobowość kobiet i mężczyzn w rozwoju: różnice generacyjne i kulturowe. "Psychologia Rozwojowa” nr 10 (2).

Mandrysz, W. (2003). Pteć: między biologia a kulturą. "Pisma Humanistyczne” nr 5.

McCleskey, J. A. (2014). Situational, Transfomational, and Transactional Leadership and Lea dership Development."Journal of Business Studies Quarterly” No. 5(4).

Moczydłowska, J. (2017a). Percepcja cech i zachowań osób na stanowiskach kierowniczych przez pryzmat ich ptci. "Zarzadzanie Zasobami Ludzkimi” nr 3-4(116-117).

- (2017b). Płeć osób na stanowiskach kierowniczych a efektywność zarządzania. "Przedsiębiorczość i Zarzadzanie" nr 18(11).

Mroziewski, M. (2005). Style kierowania i zarzadzania. Warszawa: Centrum Doradztwa i Informacji Difin.

Mrówka R. (2010). Przywództwo w organizacjach. Analiza najlepszych praktyk. Warszawa: Wolters Kluwer Polska.

Newport, F. (2001). Americans see women as emotional and affectionate, men as more aggressive: Gender specific stereotypes persist in recent Gallup poll [Access: 10.01.2020]. Access on the internet: https://news.gallup.com/poll/1978/americans-see-womenemotional-affectionate-men-more-aggressive.aspx

Oleksyn. T., Oleksyn, A. E. (2008). Menedżerowie a liderzy. "Zarządzanie Zasobami Ludzkimi” nr 3-4.

Penc, J. (2007). Nowoczesne kierowanie ludźmi. Warszawa: Centrum Doradztwa i Informacji Difin

Piskorz, Z. (2012). Style kierowania - ile ich jest? "Prace naukowe Uniwersytetu Ekonomicznego we Wroctawiu” nr 249.

Pufal-Struzik, I. (2017). Aktywność zawodowa wspótczesnych kobiet - trudności w realizacji nowych ról i tradycyjnych obowiązów. "Polskie Forum Psychologiczne” nr 22.

Stoner, J. (1999). Kierowanie. Warszawa: Polskie Wydawnictwo Ekonomiczne.

Kubiak, H. (1993). Stereotypy etniczne a komunikacja międzynarodowa, "Przegląd Polonijny” nr 4.

Sebastian, J., Moon, J. (2017). Gender Differences in Participatory Leadership: An Examination of Principals' Time Spent Working with Others. "International Journal of Education Policy \& Leadership” nr 12(8). DOI: 10.22230/ijepl.2017v12n8a792.

Sule, A., Seda, E., Kubilay, E., Loranth, G. (2019). Understanding Gender Differences in Leadership. "Economic Journal”. DOI: 10.1093/ej/uez050.

Vasta, R., Haith, M. M., Miller, S. A. (2001). Psychologia dziecka. Warszawa: Wydawnictwo Szkolne i Pedagogiczne. 
Van Engen, M.L., Willemsen, T.M. (2004). Sex and leadership styles: A meta-analysis of research published in the 1990s. "Psychological Reports" No. 94(1). DOI: 10.2466/ pr0.94.1.3-18.

Żukowski, P., Galla, R. (2009). Style kierowania przejawiane przez menedżerów w zarządzaniu organizacja, "Problemy Profesjologii” nr 1.

DOI: $10.7862 /$ rz.2021.hss.10

The text was submitted to the editorial office: March 2020.

The text was accepted for publication: March 2021. 